\title{
Neo-Nationalism: A Tool for National Integrity
}

\section{Manish Aryal}

\begin{abstract}
An ever-growing trend of radical rightist parties has brought newer dynamics to world politics. Neo-nationalism has further substantiatednational integrity for changing the socio-cultural, economic and political landscape brought by globalization during the 1980s. The paper intends to analyze the concept of neo-nationalism. The paper explores this concept through an intensive study of the origin and background of neonationalism. In the paper, a study is conducted on the use of national integrity and patriotism to implement the concept of neo-nationalism in those countries. The major precautions in adopting the neo-nationalism concept are discussed in the project. A deep study is undertaken to investigate reasons that have led the world on a modern neo-nationalist order are discussed. Four peculiar reasons, in particular, the oil crisis, the collapse of the USSR and 9/11, financial and refugee crisis, and new nationalists focusing on national integrityhave remainedkey contributors to the formation of the neo-nationalist society in the modern world. The paper studies all the reasons in depth and analyzes the key factors which might determine the new world order. The paper also uses two contemporary examples of Scotland and Western Europe to study the effects of neo-nationalism. A proper
\end{abstract}

comprehensive study is done to recognize the concept of neo-nationalism and its effect on societies. The positive and negative effects are expanded to formulate a better cohesive study. Neo-nationalism is found to be a double-edged sword with monumental benefits and drawbacks. Its concept must be adopted with proper care and precaution so that major extremity groups wouldn't be formulated.

Keywords: neo-nationalism, national integrity, native populist, nationalist, globalization

\section{Introduction}

Neo-nationalism is a complicated concept of national integrity which has risen to prominence throughout the years. The paper analyzes the concept of Neo-nationalism and related the focus of national integrity to establish and develop this concept. The effect and variation of neo-nationalism are explained through various contemporary and coherent examples. The overall background and factors causing the rise of neo-nationalism are discussed. The varying benefits and drawbacks related to adopting the neo-nationalism concept for a country is mentioned.

Neo-nationalism is growing rampantly in the current $21^{\text {st }}$ century. The growth of 
neo-nationalism caused adverse effects on various personnel groups and countries. Neonationalism has brought a change in how people, system, and even government operate. The feeling of national integrity in the past was romanticized and later philosophized. Now, the same feeling has brought about a change in the political landscape: Neonationalism, a concept that has been rooting deep inside society ever since the late 1980s.

Neo-nationalism within itself brings challenges to various factions of society. The radicalization of neo-nationalism has swept Hindu countriesincluding India deeming implications lasting years and years (Mawdsley, 2006, p. 382). The various neonationalist assumptions have affected trade, tourism and even cross-cultural linkage. Lee (2016, p. 23) stated that neo-nationalism has brought a colossal resistance against the mixing of multi-cultural and multi-ethnic groups. It even has led to discriminatory and subtle stereotyping of international students. The discrimination has led to the radicalization of various social groups. It also justifies the fact that neo-nationalism has brought more resistance to intermixing amongst people of various races.

Neo-nationalism brought not only negative impacts but also positive changes in societies. The concept in its core has promoted the preservation of cultural and religious standards set by native ethnicities. Neo-nationalism has flourished the socioeconomic landscape of various nations through a focus on the development of local product and promotion of independence. It has led to a higher following of law and order as well as increased respect towards the national military. O'Leary (2001, p. 280)state that neo-nationalism had developed a feeling of merit amongst the people. The feeling of merit created the human factions to develop a sense of togetherness. Neo-nationalism helped to connect the various local ethnicities under one banner.

Division amongst people has always been present in human history. The nationalist division and division of states based on their cultural and religious philosophies were common even since the traditional ages. It was the feeling of pride and conformity which led to wars in the past (Fukurai \& Alston, 1992, p. 212). Parties have been running with the slogan of nationalism and economic prosperity to come to power throughout the years. "The prosperity of neo-nationalism has led to the growth of right-wing philosophy all over the world"(Penney \& Wakefi, 2008, p. 145). The rise of right-wing philosophy has shifted the global political dynamics. There has been a sudden rise of right-wing parties and the supports for those parties have been increasing in recent years.

Neo-nationalism has led to the rise of nationalist parties in Japan, France, Britain, the United States, Scotland and many more. The rise of NarendraModi and Donald Trump was brought up by the rise in neonationalists philosophies in those countries. The fall of Britain from the European Union was also due to the rise of neo-nationalism in the United Kingdom. The rise of national integrity has led people to a path of inevitable future division. "Neo-nationalism has created a drift in the way countries approach foreign policy"(Isajiw, 2016, p. 12). The way that countries currently look at foreign policy is much different in comparison to previous years. The foreign policy has been focused onthe attunement of one's resources above everything else. It has led to both positive and negative side effect in the development of various countries. 
Neo-nationalism has led some countries on a prosperous path while others have fallen victim to this newer concept. It is crucial to understand the key factors, history and effects of neo-nationalism. A study of the varying consequences also must be carefully analyzed to grasp a comprehensive view of the subject matter.

\section{Methodology}

\section{Methods and Techniques}

The manuscript analyzes the concept of neonationalism through the study of history and rich background. Thesix generic methods of the qualitative assessment provide an informed and comprehensive study (Templier \& Paré, 2015, p. 115). The methods used in the paper for deriving relevant information are discussed in Figure 1.

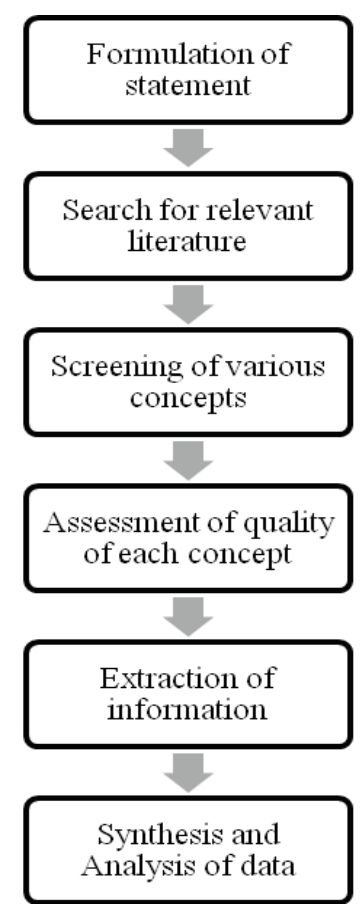

Figure 1 Methodology of the project (Templier \& Paré, 2015, p. 117)

\section{Tools, Concepts and Perspectives}

The comparative analysis conducted in the project is done through qualitative assessment. The literature aboutvarious instances and terminologies is collected and the quality of each assessment is discussed thoroughly. The paper informs the readers regarding the perspective of literature drawn from nationalists, anti-nationalist, historians and philosophers. Paper uses a holistic approach to accumulate information and derive a conclusion based on an objective study.

\section{Globalization and Declination of Nationalism}

Globalization is a multifaceted and complex interdependent wool system which is weaved between citizen and their countries. Nationalism had led man on a path of war and destruction. The people realized they needed to be interdependent to sustain a level of economic equality. The rise of poverty and loss of resources during World War II facilitated the cooperation among various countries in a single banner. Tourism and trade flourished. The fall of nationalism was due to chauvinistic ideologies with a monolithic vision. A future that encompassed all human beings as an entity was sought out to be the future.

Globalization brought a solution to solve this problem on a global scale. The end of poverty, disparaging wave gaps and the need for economic support created a backbone forthe establishment of globalization. During the cold war, countries also bounded together for protection amongst the two superpowers. The United States of America (US) and the Soviet Republic were engaged in a 50-yearold cold war amongst each other. The World War had led the two super giant's among a 
collision path. The world,to stand a visible hope and chance against the two bounded together. Smaller countries looked towards each other as a form of military support and economic strength.

Military need and demand deemed the countries to encompass the principles and ideologies brought over by globalization. At this point, nationalism was slowly vanishing and people were looking at the earth as a whole big entirety(Fischer, 2003, p. 27). The establishment of the earth as a big entity led to a decrease in nationalism. It in turn led to a more globalized form of earth. Amin (2003, pp. 39-40) observed that nationalism was vanishing towards that time. Globalization was slowly taking over the world. The core philosophies of nationalism were getting lost and globalization was dominating the whole earth. Globalization had become the central part of world politics.

\section{Rise of Unforeseeable Circumstances}

Globalization was booming and all the central political situation of globalization were attheir top during the 1960s. The fall of axis power during the world war and the expansion of allies influence after the warsignaled that the world was being encompassed as one(Bergmann, 2020, p. 235). Newer unprecedented circumstances gave rise to the growing political landscape brought by Nativist Populist. It can be stated that neo-nationalism didn't start distinctly bur developed in people's mind slowly through the variant circumstances in the preceding decades.

\section{Oil Crisis}

The first circumstances which rose thought contemporary neo-nationalism to Western and European politics happenedwhenthe
Organization of the Petroleum Exporting Countries (OPEC) oil crisis quadrupled the cost of oil during the early 1970s. At that time, the major consumers West Europe, the United States and Japan consumed more than 50\% of the world energy. Arab countries of OPEC retaliated against the West when the West supported Israel in the war against Egypt. The crisis caused the West capitalist economy to recess while simultaneously causing the US dollar to undergo mild inflation. It, in turn, led the West to restructure their economyin two ways either by reducing dependency on oil or bolster their military to take aggressive steps to secure its energy sources."After this, the oil prices grew and the West economy continued to stagnate in the 1970s"(Kettel, 2020 , p. 17). The rise of oil prices caused the countries to look after one other not focusing on global combined development. It led tothe establishment of the core philosophy of neonationalism which would blossom throughout the decades.

\section{Collapse of Communism with USSR and 9/11}

At the end of the cold war, liberal democracy became a wide brought phenomenon over the world. The west influence over global politics came rising when the Berlin Wall fell in 1989. The end of the cold war signaled the end of the USSR. With the subsequent collapse of the USSR, communism collapsed in almost all countries of Eastern Europe. The countries through their newfound pride towards their land looked at national integrity to bring the country together.

Even if the east had found their newborn admiration to the country the west was high on globalism till 2001. In September 2011, a plane en route to California flew straight into the World Trade Center in New York. The action was among one of the deadliest terrorist 
attack on Earth killing 2996 people while injuring 6000 others. The action redeemed the admiration the people had towards the military. The pride in the country sovereignty grew and many Americans were found to have developed radical right philosophies during this time.Islamophobia was stated to be started after the incident on 9/11.

\section{Financial and Refugee Crisis}

In 2008, the global economical landscape took a turn for the worse. The Financial Crisis took over people's livelihoods and collapsed the political as well as military landscapes which had been building for about decades.

At the same time, the refugee crisis roared rampant amongst the world due to wars in the Middle East. Syrian and African refugee crisis plagued the global economy bringing chaos to the established politician order. When the world's economy was burning, it became crucial to focus on booming one's national economy. Major populist's parties came into governance all over Norway, Greece, Austria and Switzerland." The new world order was in the books"(Bergmann, 2020, p. 190).The financial and refugee crisis had led the work to formulate a new world order. The rise of populist parties also seconded the motion created by the refugee crisis.

\section{Rise of the Feeling of National Integrity}

In the changing political landscape brought about by the above three waves, a new form of nationalism had been developed. The peoples love for the nation was at an all-time high and a feeling of patriotism was booming among the people. People took pride and looked towards the military for bringing a sense of national integrity. The respect for military personnel and veterans ran rampant.
Many politicians ran with the concept of newly formed neo-nationalism at its forefront. The protection of one's national integrity was at the top of the list for those politicians. The newly formed waves causedBrexit, won Marine Le Pen the second round in route to become president and even took Donald Trump to power in the States.

\section{Neo-nationalism and its Effects}

The world has been back to a combination of nations. Various terrorist, economic, and migratory reasons have caused countries to look inward and built up walls along their borders. Antonsich (2017, p. 3) stated that Nationalism has developed a new meaning in the situation today compared to one's in ancient times. People have been developing a strong bond with their country. And, thus, people are developing a smaller form of hatred toward other people from different country by hailing ones as elite. A term scholar like to define as neo-nationalism(Feischmidt \& Pulay, 2017, p. 310). Neo-nationalism has both positive and negative impacts on the overall landscape of a country. The effect of neo-nationalism has varied differently based on the implementation of its core philosophies.

\section{Effect in Scotland}

After the end of the Cold War, the threat of unification didn't loom as much of a need as it did once when the threat of another world war was imminent. Scottish National Party (SNP) during this time supported independence from the country from theEuropean Union (EU). The establishment of a neo-nationalist majority in Scotland has kept the national, economic and cultural identity of the country intact. The country has flourished through this neo-nationalist movement. Scotland has developed various paradiplomacies with 
international sovereign states. Paquin (2016, p. 39) stated that the relationships have allowed the country to define its relationship concretely defining the interest of the country as one above any individual or third-person domains. It caused the Scottish government to put their needs above everyone else in the world.

\section{Effect in Western Europe}

Western Europe in recent time has seen a rise in radical right parties. The study by Eger and Valdez uses Manifesto Project Data to analyze the attitude of voters towards contemporary party platforms. In the voting trend analysis from 1970 to 2010 , voting is found to increase in the party which holds a higher claim to nationalist philosophy. These parties were found to oppose the concept of multiculturalism and favoured a traditional nationalist way of life. It is found that not only parties have endorsed the concept of neonationalism but neo-nationalism has brought out the inner pettiness which people holding withinconcerning one another. This has given birth to radical purists who have embraced the concept of anti-multiculturalism and antiimmigration. It subsequently has caused a certain rise in hate crime against a defined demographic group(Eger \& Valdez, 2015, p. 125). The rise in hate crime caused division amongst various ethnicities. The division created barriers amongst people of various cultures. The division also created difficulties in understanding each other's culture and influenced world politics.

\section{Influences in Modern Politics}

Neo-nationalism has embedded itself into the modern political hemisphere. The world was reconfiguring to a newer dynamic structure. The need and reason why countries looked at nationalism can be seen through the example below.
In the spring of 2005, a constitutional proposal in the EU was rejected by the Dutch and French. The governor of Austria JorgHaider demanded popular voting but the Dutch and French intervened. Various countriesincluding Britain backed out from their independent decision and supported the French. Austria was persistent but the EU's approach to looking at Austria's opinion as 'business as usual' showed the alliances of the union to a bigger country alienating somewhat of a small one. The move by Haider during the Unions work helped showcase countries the unavoidable circumstances that come due to Globalization.

McCrone (2011, pp. 8-10) stated that after people looked towards nationalism, the eminent growth of neo-nationalism was imminent for the countries. The rise of Trump's republican philosophy has given a new voice to right-wing extremist in the west. As a result, there has a large increase in hate crime in the west. Newer right-wing militia group have been formulated in the name of protection of 'National integrity'. Neo-nationalism might have given a voice to some people but it has stolen it from other people. "The establishment of NarendraModi as the Prime Minister of India has also given birth to radical Hindu extremists who are blind nationalist"'(Gingrich, 2006, p. 200). The rise of radical extremists has led to a rise in hate crimes in India. Neo-nationalism may be beneficial but also has certain drawbacks. The concept must be adopted with a sight of precaution.

\section{Conclusion}

Neo-nationalism is a very intricate and variant political philosophy. Nations need to be a source of cultural organization and act as a symbol of social solidarity to their 
constituents. A cosmopolitan variation is however existent in every city of the world in terms of neo-nationalism.

The existence of policies on a territorial basis creates nationalist to develop affection towards their cultural emblems and traditions. National identity is conserved and even celebrated in neo-nationalism. Neonationalism brings about an increase in love and admiration for the government including support to the military branches. The power of goods and capital production increases substantially in neo-nationalist countries. It allows countries that embed this system to become self-reliant.

The neo-nationalist policy however is found to give rise to radical rightist parties in recent times. The countries which have gone for a neo-nationalist change have been found to develop radical rightist concepts within a short duration of time. Racial discrimination is running rampant in those countries. There is distinct hate towards people from non-populists communities in those neonationalist countries. Also, discrimination, extreme forms of radicalization are found in these states. Islamophobia, extreme protectionism and a variation of fascism are some of the extreme variant consequences which a country may undergo due to neonationalism.

Centralist and moderates suggest that the combination of neo-nationalism and globalization must dominate the imminent future for peace and prosperity. An adaptation of neo-nationalization or globalization to an extremist degree may lead to catastrophe and chaos. An ample amount of work is needed to see how inclusive neo-nationalism policies are to improve the overall discourses in a secular country. Nationalist policies need to be monitored and correctly evaluated to blur the line between complete isolation and total globalization.

\section{Recommendation}

The concept of neo-nationalism must be correctly adapted to bring prosperity to the country. Neo-nationalism may be a tool to promote and develop national integrity but adaptation to its extremist's belief will cause a country to deteriorate down the rabbit hole. But if done in the right way neo-nationalism will lead the country to the path of prosperity promoting national unity and integrity along the way.

For a country to properly adapt to this philosophy, certain procedures must be adopted. A proper definition of the neonationalist policy must be done foremost. The country trade policies and regulation with international countries must be agreed upon and defined properly. A continual focus must be shed toward self-independence and productions will lesser focus on imported goods. Para diplomacies must be established within the system. The entire political system must follow the mentioned suggestions to adapt tothe philosophy of neo-nationalism.

The concept of neo-nationalism must be opted for with a proper check and balance system. The positive aspects of national integrity and unity should be cherished. The major focus must be to develop economical independence in the country. Neo-nationalism is a twosided sword and a mere adaptation must be done by choosing the blunter side such that a beneficial outcome is reached with minimal distortion of peace and prosperity.Thus, a country and its citizen must adopt neonationalism with proper care and precaution. 


\section{References}

Amin, A. (2003). Review of International Political Economy:Editor'snote. ReviewofInternational Political Economy, 10(1), 1. https://doi. org/10.1080/0969229032000048853

Antonsich, M. (2017). The return of the nation : when neo-nationalism becomes mainstream. Society \& Space., 1-4.

Bergmann, E. (2020). Neo-nationalism: The Rise of Nativist Populism. Reykjavik, Iceland: Palgrave Macmillan: $1^{\text {st }}$ ed. 2020 edition

Eger, M. A. \& Valdez, S. (2015). Neo-nationalism in western Europe. European Sociological Review, 31(1), 115-130. https://doi. org/10.1093/esr/jcu087

Feischmidt, M. \& Pulay, G. (2017). 'Rocking the nation': the popular culture of neonationalism. Nations and Nationalism, 23(2), 309-326. https://doi.org/10.1111/nana.12264

Fischer, S. (2003). Globalization and its challenges. American Economic Review, 93(2), 1-30. https://doi.org/10.1257/000282803321946750

Fukurai, H., \& Alston, J. P. (1992). Sources of neonationalism and resistance in Japan. Journal of Contemporary Asia, 22(2), 207-223. https:// doi.org/10.1080/00472339280000161

Gingrich, A. (2006). Neo-nationalism and the reconfiguration of Europe. Social Anthropology, 14(2), 195-217. https:/doi. org/10.1017/S0964028206002539

Isajiw, C. P. (2016). Neo-Nationalism in the Foreign Policy of the Putin/Medvedev Regime. E-International Relations. https:// www.e-ir.info/2016/06/22/neo-nationalismin-the-foreign-policy-of-the-putinmedvedevregime/
Kettel, S. (2020). Oil Crisis. Encyclopcedia Britannica. https://www.britannica.com/topic/ oil-crisis

Lee, J. J. (2016). Neo-Nationalism: Challenges for International Students. International Higher Education, 84, 23-24. https://doi.org/10.6017/ ihe.2016.84.9117

Mawdsley, E. (2006). Hindu nationalism, neotraditionalism and environmental discourses in India. Geoforum, 37(3), 380-390. https:// doi.org/10.1016/j.geoforum.2005.06.004

McCrone, D. (2001). Neo-Nationalism In Stateless Nations. Scottish Affairs, 37 (First(2), 3-13. https://doi.org/10.3366/scot.2001.0062

O'leary, B. (2001). An iron law of nationalism and federation?: A (neo-Diceyian) theory of the necessity of a federal Staatsvolk, and consociational rescue. Nations and Nationalism, 7(3), 273-296. https://doi. org/10.1111/1469-8219.00017

Paquin, S. (2016). Nationalism and Ethnic Politics Globalization, European integration and the rise of neo-nationalism in Scotland Globalization, European Integration and the Rise of Neo-nationalism in Scotland. October 2012, 37-41. http://www.tandfonline.com/ action/on?journalCode=fnep $20 \% 5 \mathrm{Cnhttp} / / /$ dx.doi.org/10.1080/13537110208428653

Penney, M. \& Wakefi, B. (2008). Right Angles: Examining Accounts of Japanese Neonationalism. JSTOR, 2(September 2006), 142-147.

Templier, M. \& Paré, G. (2015). A framework for guiding and evaluating literature reviews. Communications of the Association for Information Systems, 37(August), 112-137. https://doi.org/10.17705/1 cais.03706 